\title{
Photochemical generation of the 2,2,6,6-tetramethylpiperidine- 1-oxyl (TEMPO) radical from caged nitroxides by near-infrared two-photon irradiation and its cytocidal effect on lung cancer cells
}

\author{
Ayato Yamada ${ }^{1}$, Manabu Abe ${ }^{* 1,2,3}$, Yoshinobu Nishimura ${ }^{*}$, Shoji Ishizaka ${ }^{1,2}$, \\ Masashi Namba ${ }^{2,5}$, Taku Nakashima ${ }^{2,5}$, Kiyofumi Shimoji ${ }^{5}$ and Noboru Hattori ${ }^{* 2,5}$
}

\section{Full Research Paper}

\section{Address:}

${ }^{1}$ Department of Chemistry, Graduate School of Science, Hiroshima University, 1-3-1 Kagamiyama, Higashi-Hiroshima, Hiroshima 739-8526, Japan, ${ }^{2}$ Hiroshima Research Centre for Photo-Drug-Delivery Systems (HiU-P-DDS), Hiroshima University, 1-3-1 Kagamiyama, Higashi-Hiroshima, Hiroshima 739-8526, Japan, 3JST-CREST, K's Gobancho 6F, 7, Gobancho, Chiyoda-ku, Tokyo 102-0075, Japan, ${ }^{4}$ Graduate School of Pure and Applied Sciences, University of Tsukuba, 1-1-1 Tennoudai, Tsukuba, Ibaraki 305-8571, Japan and ${ }^{5}$ Department of Molecular and Internal Medicine, Graduate School of Biomedical \& Health Sciences, Hiroshima University, 1-2-3 Kasumi, Minami-ku, Hiroshima, Hiroshima 734-8551, Japan

Email:

Manabu Abe* - mabe@hiroshima-u.ac.jp; Yoshinobu Nishimura* nishimura@chem.tsukuba.ac.jp; Noboru Hattori ${ }^{*}$ -

nhattori@hiroshima-u.ac.jp

* Corresponding author

Keywords:

caged compound; nitroxide; photolysis; radical; theranostics; two-photon

\author{
Beilstein J. Org. Chem. 2019, 15, 863-873. \\ doi:10.3762/bjoc. 15.84 \\ Received: 01 February 2019 \\ Accepted: 16 March 2019 \\ Published: 10 April 2019 \\ This article is part of the thematic issue "Reactive intermediates part I: \\ radicals". \\ Guest Editor: T. P. Yoon
}

(C) 2019 Yamada et al.; licensee Beilstein-Institut.

License and terms: see end of document.

\footnotetext{
Abstract

Novel caged nitroxides (nitroxide donors) with near-infrared two-photon (TP) responsive character, 2,2,6,6-tetramethyl-1-(1-(2-(4nitrophenyl)benzofuran-6-yl)ethoxy)piperidine (2a) and its regioisomer $\mathbf{2 b}$, were designed and synthesized. The one-photon (OP) $(365 \pm 10 \mathrm{~nm})$ and TP (710-760 nm) triggered release (i.e., uncaging) of the 2,2,6,6-tetramethylpiperidine-1-oxyl (TEMPO) radical under air atmosphere were discovered. The quantum yields for the release of the TEMPO radical were $2.5 \%(\mathbf{2 a})$ and $0.8 \%$ (2b) in benzene at $\approx 1 \%$ conversion of 2 , and $13.1 \%$ (2a) and $12.8 \%$ (2b) in DMSO at $\approx 1 \%$ conversion of 2 . The TP uncaging efficiencies were determined to be $1.1 \mathrm{GM}$ at $740 \mathrm{~nm}$ for $\mathbf{2 a}$ and $0.22 \mathrm{GM}$ at $730 \mathrm{~nm}$ for $\mathbf{2 b}$ in benzene. The cytocidal effect of compound $\mathbf{2 a}$ on lung cancer cells under photolysis conditions was also assessed to test the efficacy as anticancer agents. In a medium containing $100 \mu \mathrm{g} \mathrm{mL}^{-1}$ of $\mathbf{2 a}$ exposed to light, the number of living cells decreased significantly compared to the unexposed counterparts (65.8\% vs $85.5 \%)$.
} 


\section{Introduction}

Nitroxides (aminoxyl radicals) possess a delocalized unpaired electron and exhibit negligible dimerization reactivity, making them persistent open-shell species [1-4]. In addition to their ease of handling, nitroxides are highly sensitive to electron paramagnetic resonance (EPR) spectroscopy and redox reactions. Therefore, nitroxides have been developed and utilized in diverse and crucial applications, not only in chemistry, but also in biology, physiology, and energy sciences. These applications include spin-labels [5-7], fluorophore-nitroxide probes [8], contrast agents in magnetic resonance imaging (MRI) [9], polarization transfer agents for nuclear magnetic resonance (NMR) [10-13], and radical batteries [14,15]. Furthermore, the efficient synthesis of polymers with narrow molecular mass distributions has been accomplished using nitroxides as a mediator, i.e., so-called nitroxide-mediated polymerization (NMP) [16-20], and the nitroxide-mediated synthesis of ketones from alcohols is also well utilized in organic synthesis [21-25]. The huge number of studies concerning nitroxides clearly indicates the importance of new methods of generating nitroxides for the future development of science and technology. Notably, in physiological studies [26-32], spatiotemporal control of nitroxide generation is a key approach for investigating the role of redox-active nitroxides in mediating oxidative stress in organisms [27-32].

In 1997, Scaiano and co-workers reported the triplet-xanthone sensitized generation of the 2,2,6,6-tetramethylpiperidine-1oxyl (TEMPO) radical from alkoxyamine 1 under ultraviolet $(355 \mathrm{~nm})$ irradiation (Scheme 1) [33]. De-aerated conditions are necessary for the triplet-sensitized generation of TEMPO due to the triplet quenching ability of $\mathrm{O}_{2}$. The polymerization reactions were initiated via photochemical reaction [34-36]. For physiological studies, however, the photochemical release of nitroxides should be achieved in the presence of $\mathrm{O}_{2}$. Thus, the triplet sensitized method may not be useful for physiological studies. The application of alkoxyamines as theranostic agents [37-40] has been proposed and reported by Brémond and co-workers $[41,42]$.

Near-infrared (NIR) photons are excellent light sources in physiological studies as this wavelength of light is less harmful to living tissue than ultraviolet irradiation. Deeper penetration of NIR photons into biological samples is possible using NIR radiation with wavelengths of $650-1050 \mathrm{~nm}\left(=27-44 \mathrm{kcal} \mathrm{mol}^{-1}\right)$. However, in general, chromophores do not absorb at such long wavelengths and the photon energy is too low for bondcleavage reactions to generate (i.e., uncage) functional molecules. For example, the bond-dissociation energy of the weak $\mathrm{PhCH}_{2}-\mathrm{OPh}$, linkage is reported to be $52.1 \mathrm{kcal} \mathrm{mol}^{-1}$ [43] These issues can be solved by using the NIR-two-photon (TP)

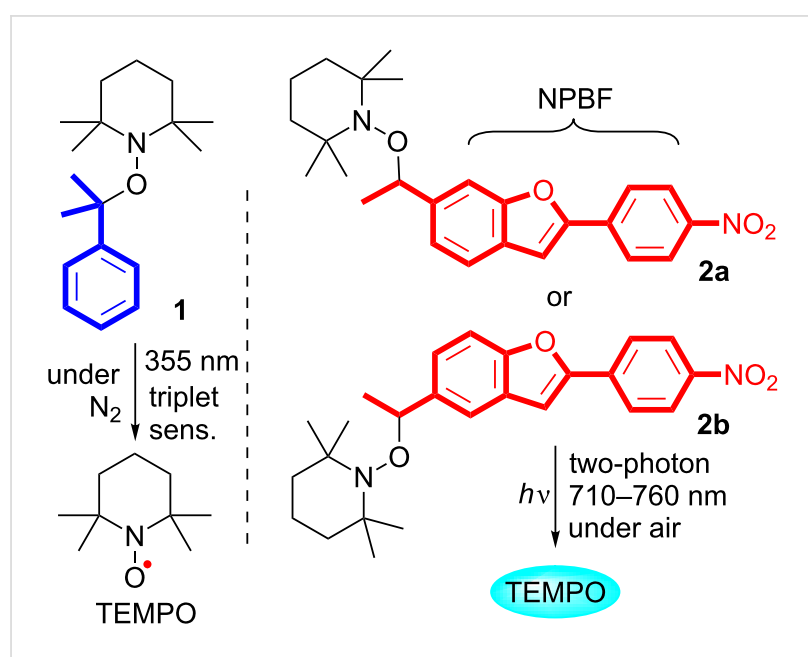

Scheme 1: Photochemical generation of TEMPO radical.

excitation technique [44], in which a molecule is electronically excited to the same state generated by one-photon (OP) excitation in the UV-vis region [45]. In addition to the advantages of TP excitation, three-dimensional control of the electronic excitation is possible because the probability of TP excitation is proportional to the square of the light intensity [46]. The lightinduced generation of nitroxides using the TP excitation technique, i.e., the concentration jump of nitroxides, is one promising method of exploring the role of these species in life phenomena [47-54] and of promoting site-selective chemical reactions such as polymerization. Very recently, Guillaneuf and co-workers reported the two-photon-induced release of nitroxides in a materials science study [55].

In the last decade, we developed a TP-responsive photo-labile protecting group [56-58] with simple cyclic stilbene structures such as 2-(4-nitrophenyl)benzofuran (NPBF) that absorb in the NIR region of $710-760 \mathrm{~nm}$ for the uncaging of bioactive substances such as glutamate and $\mathrm{Ca}^{2+}$ [59-64]. Herein, we report the synthesis of new caged nitroxides (nitroxide donors) $\mathbf{2 a}$ and $\mathbf{2 b}$ having the TP-responsive NPBF chromophore and the NIR TP-triggered generation of the 2,2,6,6-tetramethylpiperidine-1-oxyl (TEMPO) radical under atmospheric conditions using these species (Scheme 1). Because free radicals are cytotoxic due to their strong DNA-damaging activity [65], they play important roles as anticancer therapeutic agents [66]. Among the free radicals, nitroxides including the TEMPO radical have unique properties, where they can act not only as radical scavengers, but also as anticancer agents [67]. Due to the unique properties described above, nitroxides are not toxic to normal host cells and exhibit toxicity only to tumor cells. Thus, nitroxides are ideal candidates as anticancer therapeutic agents. Based on this knowledge, the cytocidal effect of the 
radical released from compound $\mathbf{2 a}$ on lung cancer cells was tested in vitro, in addition to the fundamental study.

\section{Results and Discussion}

The caged-TEMPOs $\mathbf{2 a}$ and $\mathbf{2 b}$ were synthesized as shown in Scheme 2. The new compounds, 5-ethyl- and 6-ethyl-2-(4-nitrophenyl)benzofuran (5a and $\mathbf{5 b}$ ), were synthesized from 1-ethynyl-4-nitrobenzene (4) that was prepared from the commercially available 1-iodo-4-nitrobenzene (3) [68]. The TEMPO moiety was introduced at the benzylic position of $\mathbf{5 a}$ and $\mathbf{5 b}$ using the copper-catalyzed radical reaction in the presence of tert-butyl hydroperoxide (TBHP) to afford $\mathbf{2} \mathbf{a}$ and $\mathbf{2 b}$ in $38 \%$ and 52\% yield, respectively [69]. The caged TEMPOs 2a and $2 \mathbf{b}$ were thermally stable in benzene below $320 \mathrm{~K}\left(47^{\circ} \mathrm{C}\right)$, as confirmed by electron paramagnetic resonance (EPR) spectroscopic analysis. Significant thermal decomposition of $\mathbf{2 a}$ and 2b was observed at $\approx 340 \mathrm{~K}\left(67^{\circ} \mathrm{C}\right)$, as indicated by the typical EPR signals (see Supporting Information File 1, Figure S1).

The photophysical data for the new compounds $\mathbf{2 a}, \mathbf{b}$ and $\mathbf{5 a}, \mathbf{b}$ are summarized in Table 1. The absorption maxima of com- pounds 2 and 5 were observed at $\approx 370 \mathrm{~nm}$ with a molar extinction coefficient $\varepsilon \approx 20000 \mathrm{M}^{-1} \mathrm{~cm}^{-1}$ in both benzene and DMSO. The emission profile showed a significant solvent effect. The fluorescence quantum yields in DMSO of $\mathbf{5 a}$ and $\mathbf{5 b}$ were determined to be 16.1 and $8.6 \%$, respectively, although no emission was observed from these compounds in non-polar benzene, indicating that the excited state has zwitterionic character. The charge transfer transition was supported by time-dependent density functional theory (TD-DFT) calculations for $\mathbf{5 a}$ at the CAM-B3LYP/6-31G(d) level of theory (Supporting Information File 1, Figure S2). The fluorescence quantum yields of caged-TEMPO $\mathbf{2 a}$ and $\mathbf{2 b}$ were found to be 2.9 and $2.2 \%$ in DMSO, which are much smaller than those of $\mathbf{5 a}$ and $\mathbf{5 b}$, respectively, suggesting the chemical reactivity of the singlet excited states of $\mathbf{2 a}$ and $\mathbf{2} \mathbf{b}$.

Time-correlated single photon counting (TCSPC) measurement was performed at $298 \mathrm{~K}$ in DMSO to estimate the fluorescence lifetime $(\tau)$ of $\mathbf{2}$ and $\mathbf{5}$ (Table 1). Single-exponential decay curves were observed for $\mathbf{5} \mathbf{a}$ and $\mathbf{5 b}$, respectively (Supporting Information File 1, Figure S3). The lifetimes determined by

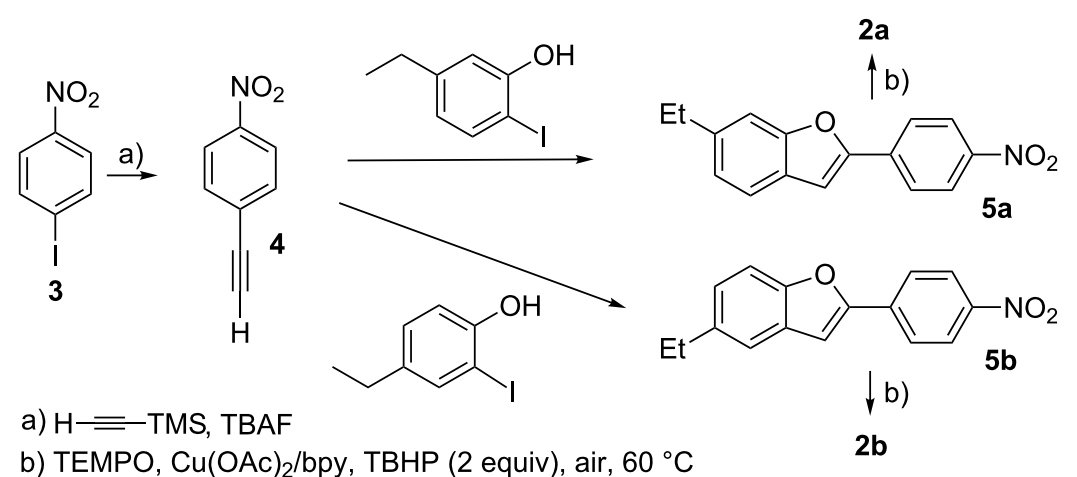

Scheme 2: Synthesis of caged nitroxides $\mathbf{2 a}$ and $\mathbf{2 b}$.

Table 1: Photophysical data for $\mathbf{2 a}, \mathbf{2 b}, \mathbf{5 a}$, and $\mathbf{5 b}$ in benzene (DMSO).

\begin{tabular}{|c|c|c|c|c|c|c|}
\hline Entry & & $\lambda_{\mathrm{abs}}[\mathrm{nm}]^{\mathrm{a}}$ & $\varepsilon\left[\mathrm{M}^{-1} \mathrm{~cm}^{-1}\right]$ & $\lambda_{\mathrm{em}}[\mathrm{nm}]^{\mathrm{b}}$ & $\Phi_{f} \times 10^{2 c}$ & $\mathrm{~T}[\mathrm{ps}]^{\mathrm{d}}$ \\
\hline 1 & $2 a$ & $\begin{array}{c}371 \\
(375)\end{array}$ & $\begin{array}{c}24800 \\
(23100)\end{array}$ & $(5 \overline{76})$ & $\begin{array}{l}\approx 0.0 \\
(2.9)\end{array}$ & $(220, \overline{1370})^{\mathrm{e}}$ \\
\hline 2 & $2 b$ & $\begin{array}{c}366 \\
(370)\end{array}$ & $\begin{array}{c}23000 \\
(23400)\end{array}$ & $(5 \overline{6})$ & $\begin{array}{l}\approx 0.0 \\
(2.2)\end{array}$ & $(390,890)^{f}$ \\
\hline 3 & $5 a$ & $\begin{array}{c}372 \\
(378)\end{array}$ & $\begin{array}{c}23800 \\
(20000)\end{array}$ & $(577)$ & $\begin{array}{c}\approx 0.0 \\
(16.1)\end{array}$ & $\frac{-}{(1430)}$ \\
\hline 4 & $5 b$ & $\begin{array}{c}367 \\
(372)\end{array}$ & $\begin{array}{c}22300 \\
(19000)\end{array}$ & $\begin{array}{c}- \\
(563)\end{array}$ & $\begin{array}{l}\approx 0.0 \\
(8.6)\end{array}$ & $(8 \overline{70})$ \\
\hline
\end{tabular}

aAbsorption maximum of $\mathbf{2 a}, \mathbf{2} \mathbf{b}, \mathbf{5 a}, \mathbf{5 b}$. ${ }^{\mathrm{b}}$ Emission maximum of $\mathbf{2 a}\left(1.18 \times 10^{-6} \mathrm{M}\right), \mathbf{2} \mathbf{b}\left(1.18 \times 10^{-6} \mathrm{M}\right), \mathbf{5 a}\left(1.16 \times 10^{-6} \mathrm{M}\right), \mathbf{5 b}\left(1.12 \times 10^{-6} \mathrm{M}\right)$. cFluorescence quantum yields. The standard sample 9,10 -diphenylanthracene $\left(\Phi_{f}=0.91\right)$ was used for determining the quantum yields. ${ }^{\mathrm{d}}$ Fluorescence lifetime monitored at $560 \mathrm{~nm}$. The concentrations were the same as those used for the fluorescence measurements. ${ }^{e}$ Each contribution is $57 \%$ and $43 \%$, respectively. ${ }^{f}$ Each contribution is $70 \%$ and $30 \%$, respectively. 
single-exponential fitting were $1430(\mathbf{5 a})$ and 870 ps (5b), respectively (Table 1, entries 3 and 4). Double-exponential decay was, however, observed for the TEMPO-substituted NPBF derivatives $\mathbf{2 a}$ and $\mathbf{2 b}$, where the lifetimes were $220(57 \%)$ and 1370 ps (43\%) for $\mathbf{2 a}$, and $390(70 \%)$ and 890 ps (30\%) for $\mathbf{2 b}$ (Table 1, entries 1 and 2). For $\mathbf{2 a}$ and $\mathbf{2 b}$, intermolecular charge transfer processes induced by the TEMPO moiety may account for the double-exponential decay curves to some extent.

OP photolysis of $\mathbf{2 a}(5 \mathrm{mM})$ was first conducted in benzene at $\approx 298 \mathrm{~K}$ using $365 \mathrm{~nm}$ light $\left(6.02 \times 10^{15}\right.$ photons s$\left.^{-1}\right)$ under atmospheric conditions (Figure 1). Clean release of the TEMPO radical was confirmed by measuring the electron paramagnetic resonance (EPR) signals of the typical nitroxide, $A_{\mathrm{N}}=15.5 \mathrm{G}$ $(g=2.00232$, Figure 1 and Figure $2 c)$. The first-order rate constant for generation of TEMPO in the bulk photoreaction was found to be $k=1.6 \times 10^{-5} \mathrm{~s}^{-1}$. The amount of photochemically released TEMPO radical was determined by comparing the EPR intensity with the calibration curve of the standard TEMPO sample (Supporting Information File 1, Figure S4). The chemi-

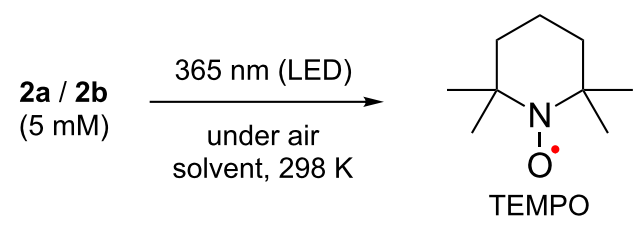

\begin{tabular}{|c|c|}
\hline solvent & $\begin{array}{c}\text { chemical yield of TEMPO } \\
\text { (quantum yield) } \\
\text { from } \mathbf{2 a / 2 b}\end{array}$ \\
\hline benzene & $\begin{array}{c}80 \% / 81 \% \\
(2.5 \% / 0.8 \%)\end{array}$ \\
DMSO & $\begin{array}{c}56 \% / 58 \% \\
(13.1 \% / 12.8 \%)\end{array}$ \\
\hline
\end{tabular}

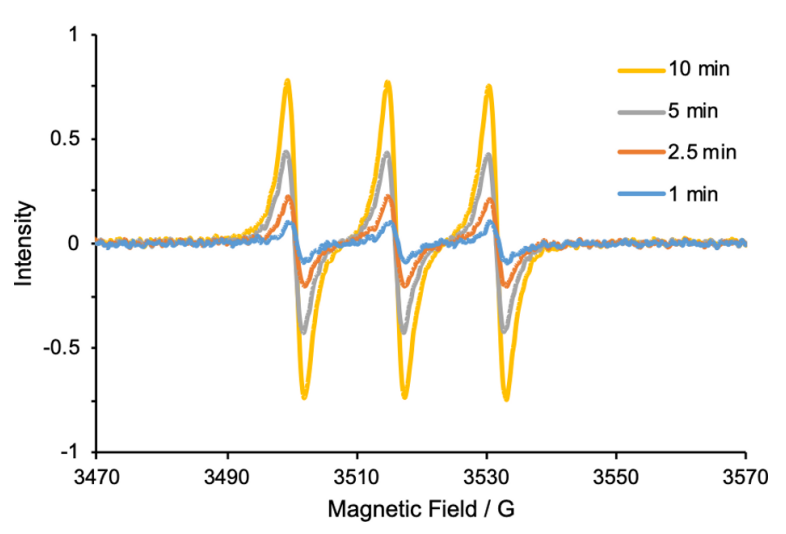

Figure 1: Photochemical generation of TEMPO from $\mathbf{2 a}$ and $\mathbf{2 b}$. EPR spectra acquired during the photolysis of $2 a(5 \mathrm{mM})$ in benzene using $365 \mathrm{~nm}$ LED light under air atmosphere. cal yield of TEMPO was $80 \%$ after 10 min irradiation in benzene under air atmosphere (Figure $2 \mathrm{~g}$ ). Secondary photoreaction of TEMPO gradually decreased the chemical yield of TEMPO. The quantum yield $(\Phi)$ for photochemical release of the TEMPO radical was $2.5 \%$ at $\approx 1 \%$ conversion in the photolysis of $\mathbf{2 a}$ in benzene under atmospheric conditions. Similar photochemical generation of the TEMPO radical was conducted with 2b (5 mM, Supporting Information File 1, Figure S5 and Figure 2d,h). The clean generation of the TEMPO radical was also observed during photolysis under $365 \mathrm{~nm}$ irradiation in benzene at $\approx 298 \mathrm{~K}$ under atmospheric conditions, although the reaction was slower than that of $\mathbf{2 a}$, $k=5.5 \times 10^{-6} \mathrm{~s}^{-1} ; \Phi=0.8 \%$ at $\approx 1 \%$ conversion of $2 \mathbf{b}$. However, the chemical yield of TEMPO was also high $(81 \%$ after 20 min irradiation under the same conditions), although slow photochemical decomposition of TEMPO was observed with prolonged irradiation (Figure $2 \mathrm{~h}$ ). In DMSO, the quantum yield
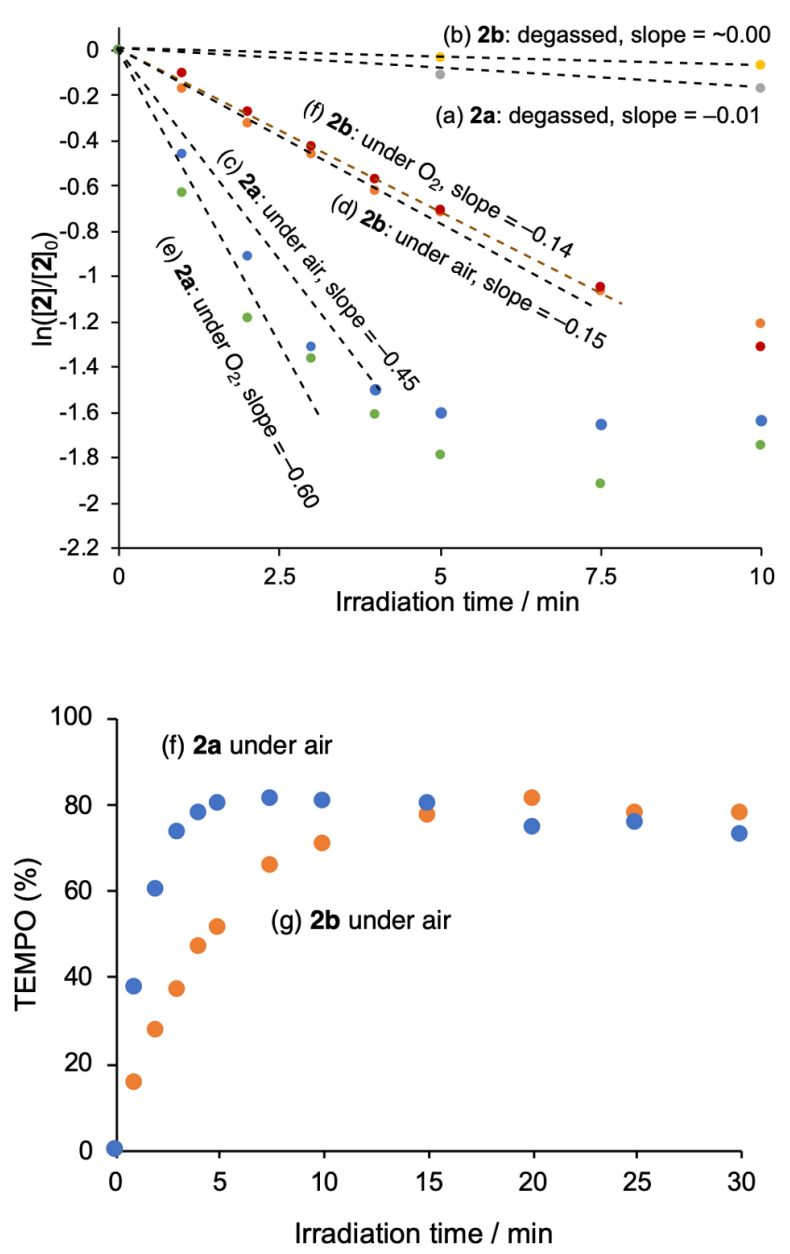

Figure 2: Time profile for photochemical generation of TEMPO radical from 2 ( $5 \mathrm{mM}$ ) at $\approx 298 \mathrm{~K}$ in benzene: (a) from $2 \mathrm{a}$ under degassed conditions, (b) from $\mathbf{2 b}$ under degassed conditions, $(c, g)$ from $\mathbf{2 a}$ under air conditions, (d,h) from $\mathbf{2 b}$ under air conditions, (e) from $\mathbf{2} \mathbf{a}$ under $\mathrm{O}_{2}$, (f) from 2 b under $\mathrm{O}_{2}$. 
for the formation of TEMPO increased significantly to $13.1 \%$ (from $\mathbf{2 a}$ ) and $12.8 \%$ (from $\mathbf{2 b}$ ) at $\approx 1 \%$ conversion of $\mathbf{2}$ under atmospheric conditions (Figure 1). The notable effect of the solvent on the TEMPO generation may be due to the increase in the lifetime of the excited states. Photochemical decomposition of TEMPO in DMSO was found to be faster than that in benzene, but the chemical yield of TEMPO (56\% from $2 \mathbf{a}$ and $58 \%$ from $\mathbf{2 b}$ after $40 \mathrm{~s}$ irradiation) was found to be lower than that obtained in benzene (Figure 1).

To obtain insight into the mechanism of generation of the TEMPO radical, the photolysis of $\mathbf{2}$ was conducted under degassed conditions using the freeze-pump-thaw (FPT) method (Figure 2a,b). Interestingly, the generation of the TEMPO radical was highly suppressed under the photolysis conditions (Figure 2a,b). Under air conditions, however, the photochemical release of TEMPO was detected in benzene, as shown in Figure 2c,d. Faster formation of TEMPO was observed when $\mathrm{O}_{2}$ atmosphere was used instead of an air atmosphere (Figure 2e,f). Therefore, the $\mathrm{O}_{2}$ molecule may play an important role in clean generation of the TEMPO radical during photolysis. Indeed, the compounds oxidized at the benzylic carbon, 6 and 7, were isolated in 15\% (15\%) and 56\% (42\%) yield in the photolysis of $\mathbf{2} \mathbf{a}$ and $\mathbf{2} \mathbf{b}$ under atmospheric conditions, respectively (Scheme 3), indicating that under degassed conditions, the photochemically generated radical pair returns to the starting compound $\mathbf{2}$ with rapid radical recombination. Over $70 \%$ of the caged TEMPO $\mathbf{2 a}$ and $\approx 85 \%$ of $\mathbf{2} \mathbf{b}$ were recovered after $2 \mathrm{~h}$ of irradiation under degassed conditions. The retarded formation of TEMPO after $5 \mathrm{~min}$ of irradiation is due to the decrease in the relative absorbance of $\mathbf{2 a}$ to those of primary photoproducts (Figure 2c,e).

The TP photolysis of $\mathbf{2 a}(10 \mathrm{mM})$ and $\mathbf{2 b}(10 \mathrm{mM})$ was carried out in benzene under atmospheric conditions using 710, 720,
730, 740, 750, and $760 \mathrm{~nm}$ near infrared light from a Ti:sapphire laser (pulse width $100 \mathrm{fs}, 80 \mathrm{MHz}$ ) emitting at an average of $700 \mathrm{~mW}$ (Figure 3 for $\mathbf{2 a}$ and Supporting Information File 1, Figure S6 for $\mathbf{2 b}$ ). The typical EPR signals of TEMPO were also observed after TP excitation of $\mathbf{2 a}$ and $\mathbf{2 b}$ (Supporting Information File 1, Figure S7). The formation of TEMPO at $740 \mathrm{~nm}, k_{740}=4.9 \times 10^{-6} \mathrm{~s}^{-1}$ in the bulk photoreaction, was the fastest in the TP-uncaging reaction of $\mathbf{2 a}$ (Figure 3). For the uncaging reaction of $\mathbf{2} \mathbf{b}$, the rate of consumption under $730 \mathrm{~nm}$ irradiation, $k_{730}=1.6 \times 10^{-6} \mathrm{~s}^{-1}$, was larger than those at other wavelengths (Supporting Information File 1, Figure S6).

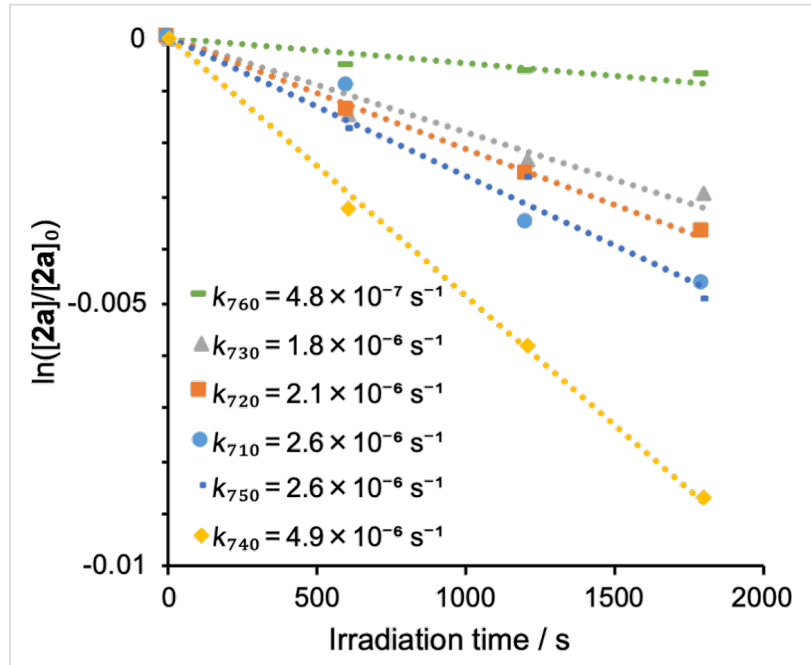

Figure 3: Time profile, $\ln \left([\mathbf{2} \mathbf{a}] /[\mathbf{2} \mathbf{a}]_{0}\right)$ versus irradiation time, of twophoton uncaging reaction of TEMPO in the photolysis of $2 \mathbf{a}$ in benzene, at wavelengths of $710-760 \mathrm{~nm}$ and power of $700 \mathrm{~mW}$.

The TP action spectra of $\mathbf{2} \mathbf{a}$ and $\mathbf{2} \mathbf{b}$ in benzene are shown in Figure 4, where the spectra were obtained by extrapolation from the absolute TP cross-section of the parent NPBF (18 GM) at

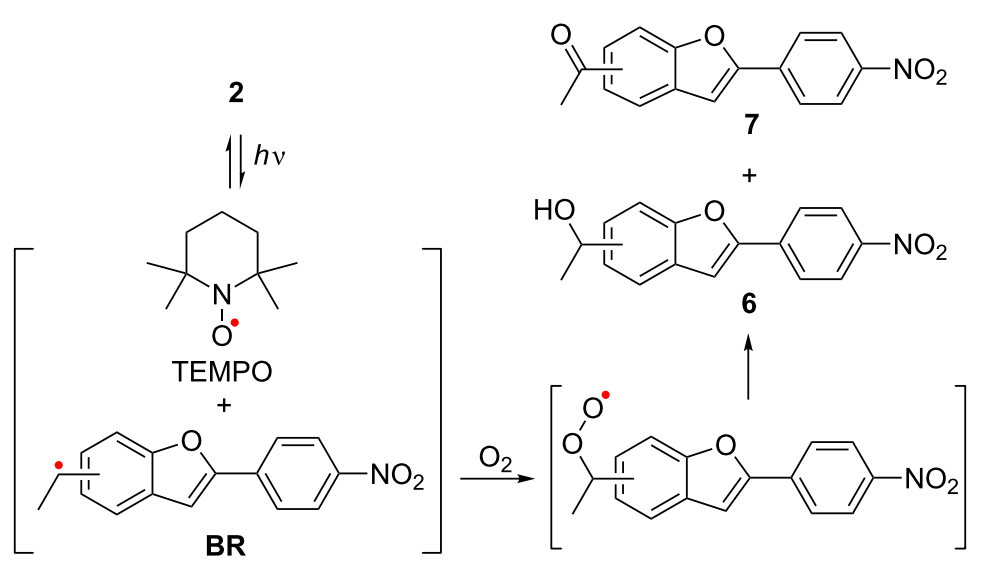

Scheme 3: Photochemical generation of TEMPO radical and photoproducts 6 and 7 under air atmosphere. 


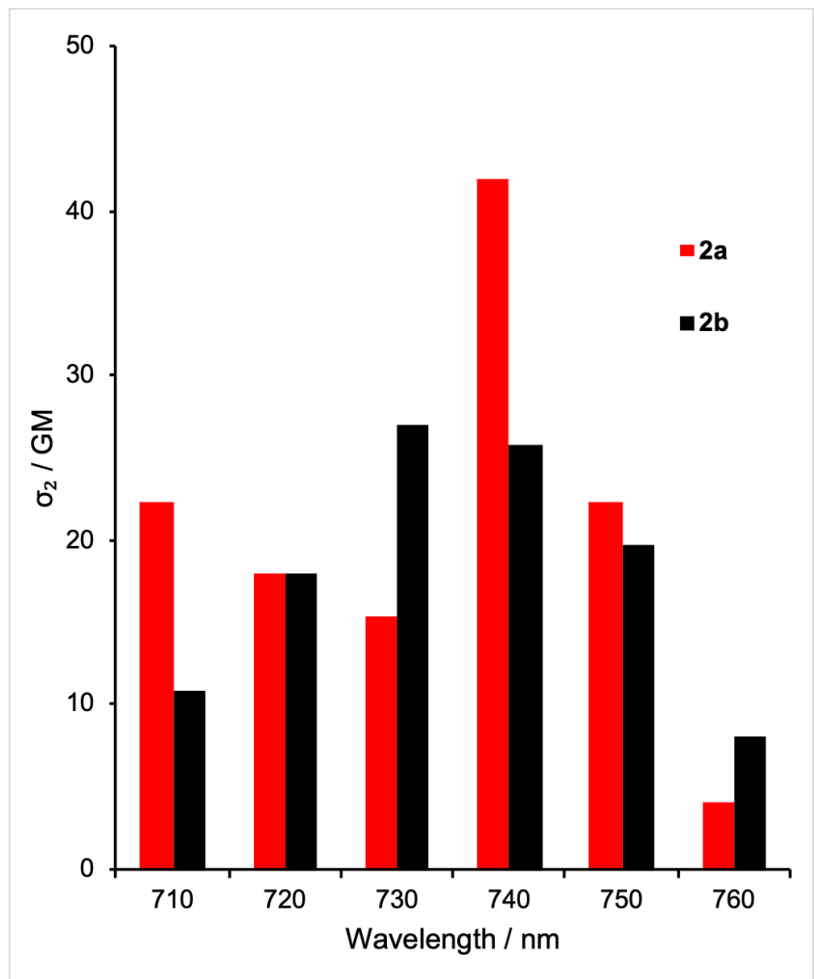

Figure 4: ESR spectra acquired during the photolysis of $2 \mathbf{a}(5 \mathrm{mM})$ in benzene using $365 \mathrm{~nm}$ light.

$720 \mathrm{~nm}$ [58]. The TP cross-section of $\mathbf{2 a}$ was higher than that of 2b by $\approx 15 \mathrm{GM}$. This higher GM value may be due to the stronger donor-acceptor character of $\mathbf{2 a}$ relative to that of $\mathbf{2} \mathbf{b}$, because the electron-donating alkyl group is located at the paraposition of the $p$-nitrophenyl group in $\mathbf{2 a}$.

As observed in the OP uncaging reaction at $365 \mathrm{~nm}$, the efficiency of the TP-induced TEMPO uncaging reaction of $\mathbf{2 a}$ was almost three times higher than that of $\mathbf{2} \mathbf{b}$ in benzene. This is attributed to the substituent effect of the meta-alkoxy group on the reactivity in the electronically excited states [70]. Moreover, the relative stability of radicals $\mathbf{B R a}$ and $\mathbf{B R b}$ generated by the photolysis of $\mathbf{2 a}$ and $\mathbf{2} \mathbf{b}$ had an important impact on the uncaging efficiency. The isodesmic reaction shown in Scheme 4 suggests the radical BRa derived from 2a was $2.04 \mathrm{kcal} \mathrm{mol}^{-1}$ more stable than BRb generated from $\mathbf{2 b}$ based on DFT calculations at the B3LYP/6-31G(d) level of theory. In DMSO, no significant difference between $\mathbf{2 a}$ and $\mathbf{2 b}$ was observed for the photochemical release of the TEMPO species, although the solvent effect is not clearly explained.

As mentioned above, the spatiotemporally controlled generation of the radical pair of TEMPO and BR was confirmed in the photolysis of compounds $\mathbf{2} \mathbf{a}$ and $\mathbf{2 b}$. Because free radicals play important roles as anticancer therapeutic agents, the cytocidal effect of the radical released from compound $\mathbf{2 a}$ was also tested in vitro using lung cancer cells. One hundred thousand Lewis lung carcinoma (LLC) cells were seeded into 24-well plates (medium: DMEM) and incubated overnight at $37{ }^{\circ} \mathrm{C}$ under an atmosphere of $95 \%$ air and $5 \% \mathrm{CO}_{2}$. The medium was replaced with fresh phenol-red free DMEM containing various concentrations of $\mathbf{2 a}\left(0,10,100 \mu \mathrm{gL}^{-1}\right)$ and further incubated for $4 \mathrm{~h}$ under the same conditions. Without exposure to light, 2 a itself exhibited slight cytotoxicity based on trypan blue exclusion, and $\approx 80-90 \%$ living cells remained in the medium containing of $100 \mu \mathrm{g} \mathrm{mL}^{-1}$ of $\mathbf{2 a}$ (Supporting Information File 1, Figure S8).

The cytocidal effect of the radicals released from compound $\mathbf{2 a}$ on LLC cells was also tested. Four hours after 1 min exposure to $360 \mathrm{~nm}$ light in various concentrations of $\mathbf{2 a}$-containing medium, the number of living cells decreased in a $\mathbf{2 a}$ concentration-dependent manner (Supporting Information File 1, Figure S9). After exposure of the cells in the medium containing $100 \mu \mathrm{g} \mathrm{mL}^{-1}$ of $\mathbf{2 a}$, the number of living cells decreased significantly compared to that without exposure $(66.5 \%$ vs $87.8 \%$, Supporting Information File 1, Figure S10). An irradiationtime-dependent decline in the viability of the LLC cells was also observed (Figure 5). To evaluate whether the cytocidal effect was due to photochemical radical generation, cells exposed to $360 \mathrm{~nm}$ light for $1 \mathrm{~min}$ and the unexposed congeners were stained by using a ROS-ID oxidative stress detection kit (Enzo Life Sciences, Farmingdale, NY, U.S.A.). Reactive oxygen species (ROS) were detected in the cells irradiated in the 2a-containing medium, but not in the non-irradiated cells in<smiles></smiles> 


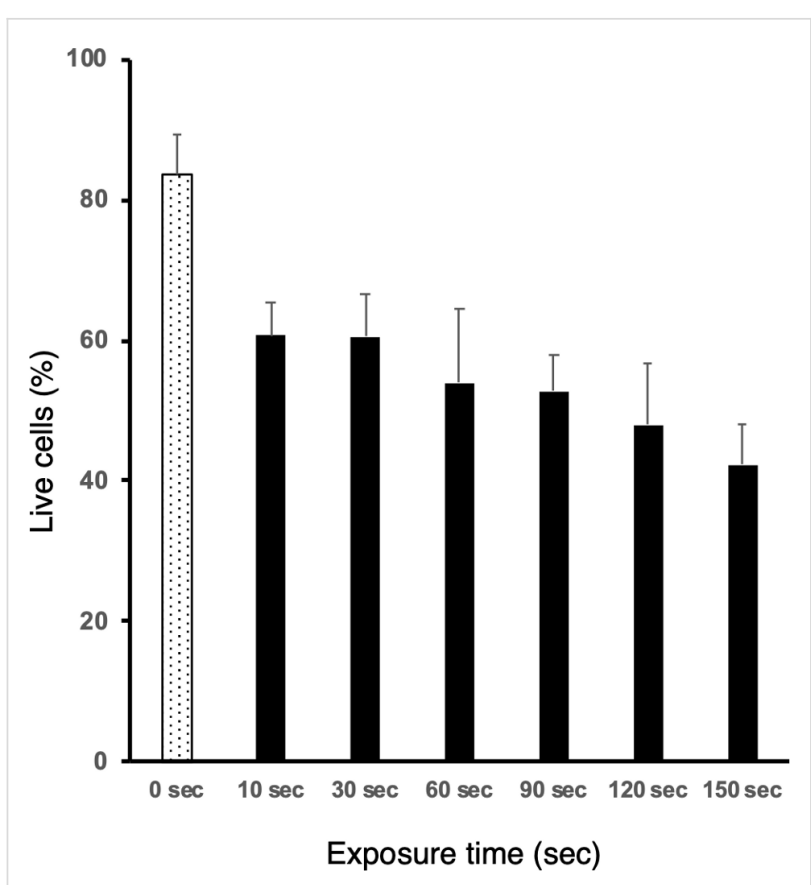

Figure 5: Irradiation time-dependent decline in viability of LLC cells with compound $\mathbf{2 a}$.

2a-containing medium or the irradiated cells without 2a-containing medium (Figure 6). Thus, the preliminary analyses indicated that the photochemical generation of radicals from $\mathbf{2 a}$ induced cancer cell death in vitro, although no in vivo study was performed because of the low water solubility of $\mathbf{2 a}$. At this point, we cannot rule out generate of ROS by photosensitization of the chromophore in the presence of $\mathrm{O}_{2}$ for the cytotoxicity.

\section{Conclusion}

In the present study, novel caged nitroxides $\mathbf{2 a}$ and $\mathbf{2 b}$ having a TP-responsive chromophore were synthesized, and OP- and TP-induced generation of the TEMPO radical with these species was examined. The quantum yields for generation of the TEMPO radical from $\mathbf{2 a}$ and $\mathbf{2} \mathbf{b}$ were determined to be $2.5 \%$ and $0.8 \%$ in benzene, respectively. The quantum yields in DMSO were found to be higher than those in benzene, $13.1 \%$ and $12.8 \%$, respectively. The OP-uncaging efficiency $(\varepsilon \times \Phi)$ was found to be 480 and 175 for $\mathbf{2 a}$ and $\mathbf{2 b}$, respectively, at $360 \pm 10 \mathrm{~nm}$, in benzene, and 3026 and 2995 in DMSO, respectively. The TP efficiency of the TEMPO uncaging reaction was found to be $1.1 \mathrm{GM}$ at $740 \mathrm{~nm}$ for $\mathbf{2 a}$ and $0.22 \mathrm{GM}$ at $730 \mathrm{~nm}$ for $\mathbf{2} \mathbf{b}$ in benzene. The TP-induced clean release of the TEMPO radical is expected to be applicable to further physiological studies and site-selective polymerization reactions.

\section{Experimental}

All reagents were purchased from commercial sources and were used without additional purification, unless otherwise mentioned. Caged nitroxides $\mathbf{2} \mathbf{a}$ and $\mathbf{2} \mathbf{b}$ were prepared according to the methods described previously (Scheme 2) and were isolated by silica gel column chromatography and GPC. ${ }^{1} \mathrm{H}$ and ${ }^{13} \mathrm{C}$ NMR spectra were reported in parts per million $(\delta)$ by using $\mathrm{CDCl}_{3}$. IR spectra were recorded with a FTIR spectrometer. UV-vis spectra were taken by a SHIMADZU UV-3600 Plus spectrophotometer. Mass spectra were measured by a Mass Spectrometric Thermo Fisher Scientific LTQ Orbitrap XL, performed by the Natural Science Center for Basic Research and Development (N-BARD), Hiroshima University.

\section{Preparation of caged compounds $\mathbf{2} \mathbf{a}$ and $\mathbf{2} \mathbf{b}$}

6-Ethyl-2-(4-nitrophenyl)benzofuran (5a). 4-Nitro-1-iodobenzene (16.3 g, $65.5 \mathrm{mmol}), \mathrm{Pd}(\mathrm{dppf}) \mathrm{Cl}_{2}(0.97 \mathrm{~g}, 1.3 \mathrm{mmol})$, $\mathrm{PPh}_{3}$ (recrystallized, $\left.0.51 \mathrm{~g}, 1.9 \mathrm{mmol}\right)$ and $\mathrm{CuI}(0.25 \mathrm{~g}$, $1.3 \mathrm{mmol}$ ) were added under $\mathrm{N}_{2}$ atmosphere followed by toluene $(97 \mathrm{~mL})$ and $i \operatorname{Pr}_{2} \mathrm{NH}(49 \mathrm{~mL}, 359 \mathrm{mmol})$. The mixture was stirred for $10 \mathrm{~min}$, and TMSA $(11.5 \mathrm{~mL}, 81.6 \mathrm{mmol})$ in toluene $(64 \mathrm{~mL})$ was added at room temperature. It was stirred until all iodobenzene was consumed (20 min). TBAF $1 \mathrm{M}$ in THF (100 mL, $100 \mathrm{mmol}$ ) was added followed by 5-ethyl-2iodophenol (21.6 g, $86.9 \mathrm{mmol})$. The temperature was increased to $80{ }^{\circ} \mathrm{C}$, and the mixture was stirred for $21.5 \mathrm{~h}$. The reaction was quenched with $10 \%$ aqueous citric acid $(400 \mathrm{~mL})$

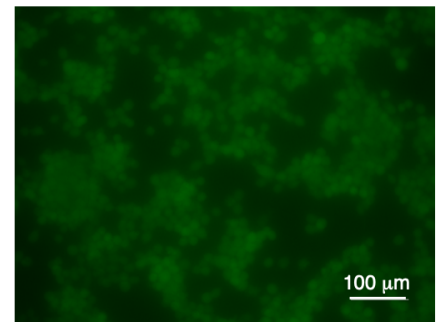

1 min exposure with $\mathbf{2 a}$

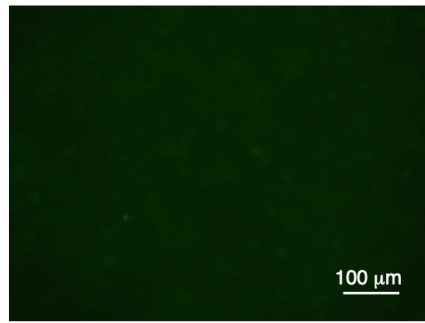

non-exposure with $\mathbf{2 a}$

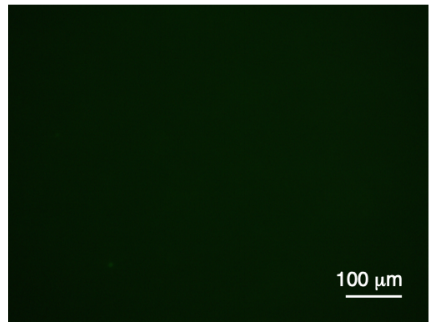

non-exposure without $\mathbf{2 a}$

Figure 6: Detection of intracellular ROS only in irradiated LLC cells with 2a-containing medium. 
and extracted with DCM. The combined extracts were washed with $10 \%$ aqueous $\mathrm{NaOH}(400 \mathrm{~mL})$, water and dried with anhydrous $\mathrm{MgSO}_{4}$. The solvent was removed by rotary evaporation and the crude product was purified by silica gel column chromatography (hexane/EtOAc 10:1, v/v) to give 6-ethyl-2-(4nitrophenyl)benzofuran (5a, $10.0 \mathrm{~g}, 57.3 \%) . \mathrm{mp} 114{ }^{\circ} \mathrm{C}$; IR $\left(\mathrm{KBr}, \mathrm{cm}^{-1}\right): 3429,2968,1601,1520,1344,1108,828,825$, 754, 692; ${ }^{1} \mathrm{H}$ NMR $\left(400 \mathrm{MHz}, \mathrm{CDCl}_{3}\right) \delta(\mathrm{ppm}) 8.30(\mathrm{~d}, J=$ $9.0 \mathrm{~Hz}, 2 \mathrm{H}), 7.98(\mathrm{~d}, J=9.0 \mathrm{~Hz}, 2 \mathrm{H}), 7.54(\mathrm{~d}, J=8.0 \mathrm{~Hz}, 1 \mathrm{H})$, 7.39 (s, 1H), $7.20(\mathrm{~d}, J=0.9 \mathrm{~Hz}, 1 \mathrm{H}), 7.14(\mathrm{dd}, J=8.0,1.4 \mathrm{~Hz}$, $1 \mathrm{H}), 2.80$ (q, $J=7.6 \mathrm{~Hz}, 2 \mathrm{H}), 1.32(\mathrm{t}, J=7.6 \mathrm{~Hz}, 3 \mathrm{H})$; ${ }^{13} \mathrm{C}$ NMR (100 MHz, $\left.\mathrm{CDCl}_{3}\right) \delta(\mathrm{ppm}) 156.05(\mathrm{C}), 152.86(\mathrm{C})$, $147.12(\mathrm{C}), 143.06(\mathrm{C}), 136.56(\mathrm{C}), 126.43(\mathrm{C}), 125.01(\mathrm{CH})$, $124.33(\mathrm{CH}), 124.07(\mathrm{CH}), 121.22(\mathrm{CH}), 110.42(\mathrm{CH}), 105.12$ (CH), $29.25\left(\mathrm{CH}_{2}\right), 15.84\left(\mathrm{CH}_{3}\right)$; HRMS-ESI $(\mathrm{m} / \mathrm{z})$ : [ $\left.\mathrm{M}^{-}\right]$calcd. for $\mathrm{C}_{16} \mathrm{H}_{13} \mathrm{NO}_{3}$, 267.09009; found, 267.09064.

2,2,6,6-Tetramethyl-1-(1-(2-(4-nitrophenyl)benzofuran-6yl)ethoxy)piperidine (2a). Under air, TEMPO (0.23 g, $1.5 \mathrm{mmol})$, 6-ethyl-2-(4-nitrophenyl)benzofuran (5a, $1.26 \mathrm{~g}$, $4.72 \mathrm{mmol}), \mathrm{Cu}(\mathrm{OAc})_{2}(16.5 \mathrm{mg}, 0.092 \mathrm{mmol})$, bpy (13.8 mg, $0.094 \mathrm{mmol}$ ), TBHP (aqueous 70\%, $0.41 \mathrm{~mL}, 2.9 \mathrm{mmol}$ ) were added into a two-necked flask in the dark. The reaction was stirred at $60{ }^{\circ} \mathrm{C}$ for $15 \mathrm{~h}$. Upon completion, the mixture was purified silica gel column chromatography (hexane/ether 15:1, $\mathrm{v} / \mathrm{v}$ ) to give 2a (236 mg, 37.8\%). mp $109{ }^{\circ} \mathrm{C}$; IR $\left(\mathrm{KBr}, \mathrm{cm}^{-1}\right)$ : 3429, 2934, 1600, 1521, 1345, 1062, 825; ${ }^{1} \mathrm{H}$ NMR (400 MHz, $\left.\mathrm{CDCl}_{3}\right) \delta(\mathrm{ppm}) 8.31(\mathrm{~d}, J=9.0 \mathrm{~Hz}, 2 \mathrm{H}), 7.99(\mathrm{~d}, J=9.0 \mathrm{~Hz}$, 2H), 7.57 (d, $J=8.1 \mathrm{~Hz}, 1 \mathrm{H}), 7.54$ (s, 1H), 7.25 (dd, $J=8.1$, $1.2 \mathrm{~Hz}, 1 \mathrm{H}), 7.21(\mathrm{~d}, J=0.7 \mathrm{~Hz}, 1 \mathrm{H}), 4.91(\mathrm{q}, J=6.7 \mathrm{~Hz}, 1 \mathrm{H})$, $1.54(\mathrm{~d}, J=6.6 \mathrm{~Hz}, 3 \mathrm{H}), 1.51(\mathrm{~s}, 3 \mathrm{H}), 1.32(\mathrm{~s}, 6 \mathrm{H}), 1.20(\mathrm{~s}, 3 \mathrm{H})$, $1.05(\mathrm{~s}, 3 \mathrm{H}), 0.66(\mathrm{~s}, 3 \mathrm{H}) ;{ }^{13} \mathrm{C} \mathrm{NMR}\left(100 \mathrm{MHz}, \mathrm{CDCl}_{3}\right) \delta$ (ppm) 155.69 (C), 153.25 (C), 147.18 (C), 144.70 (C), 136.50 (C), $127.39(\mathrm{C}), 125.08(\mathrm{CH}), 124.33(\mathrm{CH}), 122.65(\mathrm{CH})$, $121.04(\mathrm{CH}), 109.47(\mathrm{CH}), 105.13(\mathrm{CH}), 83.28(\mathrm{CH}), 59.79$ (C), $40.43\left(\mathrm{CH}_{2}\right), 34.23\left(\mathrm{CH}_{3}\right), 23.82\left(\mathrm{CH}_{2}\right), 20.40\left(\mathrm{CH}_{3}\right)$, $17.24(\mathrm{CH} 3)$; HRMS-ESI $(\mathrm{m} / \mathrm{z}):[\mathrm{M}+\mathrm{H}]^{+}$calcd. for $\mathrm{C}_{25} \mathrm{H}_{30} \mathrm{~N}_{2} \mathrm{O}_{4}$, 423.22783; found, 423.22754 .

5-Ethyl-2-(4-nitrophenyl)benzofuran (5b). 4-Nitro-1-iodobenzene (16.8 g, $67.5 \mathrm{mmol}), \mathrm{Pd}(\mathrm{dppf}) \mathrm{Cl}_{2}(1.0 \mathrm{~g}, 1.3 \mathrm{mmol})$, $\mathrm{PPh}_{3}$ (recrystallized, $0.53 \mathrm{~g}, 2.0 \mathrm{mmol}$ ) and $\mathrm{CuI}(0.26 \mathrm{~g}$, $1.3 \mathrm{mmol}$ ) were added under $\mathrm{N}_{2}$ atmosphere followed by toluene $(100 \mathrm{~mL})$ and $\mathrm{iPr}_{2} \mathrm{NH}(50.5 \mathrm{~mL}, 370 \mathrm{mmol})$. The mixture was stirred for $10 \mathrm{~min}$, and TMSA $(1.75 \mathrm{~mL}, 12.5 \mathrm{mmol})$ in toluene $(10 \mathrm{~mL})$ was added at room temperature. It was stirred until all iodobenzene was consumed (20 min). TBAF $1 \mathrm{M}$ in THF (100 mL, $100 \mathrm{mmol})$ was added followed by 4-ethyl-2iodophenol (22.22 g, $89.6 \mathrm{mmol})$. The temperature was increased to $80^{\circ} \mathrm{C}$, and the mixture was stirred for $20 \mathrm{~h}$. The reaction was quenched with $10 \%$ aqueous citric acid $(666 \mathrm{~mL})$ and extracted with DCM. Combined extracts were washed with $10 \%$ aqueous $\mathrm{NaOH}(666 \mathrm{~mL})$, water and dried with anhydrous $\mathrm{MgSO}_{4}$. The solvent was removed by rotary evaporation and the crude product was purified silica gel column chromatography (hexane/EtOAc 10:1, v/v) to give 5-ethyl-2-(4nitrophenyl)benzofuran $(5 \mathbf{b}, 12.2 \mathrm{~g}, 67.6 \%)$. mp $129^{\circ} \mathrm{C}$; IR $\left(\mathrm{KBr}, \mathrm{cm}^{-1}\right): 2922,1601,1514,1340,1194,853,811,754,690$; ${ }^{1} \mathrm{H}$ NMR $\left(400 \mathrm{MHz}, \mathrm{CDCl}_{3}\right) \delta(\mathrm{ppm}) 8.30(\mathrm{~d}, J=9.0 \mathrm{~Hz}, 2 \mathrm{H})$, $7.99(\mathrm{~d}, J=9.0 \mathrm{~Hz}, 2 \mathrm{H}), 7.46(\mathrm{~d}, J=9.2 \mathrm{~Hz}, 1 \mathrm{H}), 7.44(\mathrm{~s}, 1 \mathrm{H})$, $7.21(\mathrm{dd}, J=8.4,1.8 \mathrm{~Hz}, 1 \mathrm{H}), 7.19(\mathrm{~d}, J=0.8 \mathrm{~Hz}, 1 \mathrm{H}), 2.76$ (q, $J=7.6 \mathrm{~Hz}, 2 \mathrm{H}) 1.30(\mathrm{t}, J=7.6 \mathrm{~Hz}, 3 \mathrm{H}) ;{ }^{13} \mathrm{C} \mathrm{NMR}(100 \mathrm{MHz}$, $\left.\mathrm{CDCl}_{3}\right) \delta(\mathrm{ppm}) 154.12(\mathrm{C}), 153.38(\mathrm{C}), 147.21(\mathrm{C}), 139.74$ (C), $136.47(\mathrm{C}), 128.79(\mathrm{C}), 126.24(\mathrm{CH}), 125.12(\mathrm{CH}), 124.29$ $(\mathrm{CH}), 120.14(\mathrm{CH}), 111.12(\mathrm{CH}), 105.04(\mathrm{CH}), 28.83\left(\mathrm{CH}_{2}\right)$, $16.15\left(\mathrm{CH}_{3}\right)$; HRMS-ESI $(\mathrm{m} / \mathrm{z})$ : $\left[\mathrm{M}^{-}\right]$calcd. for $\mathrm{C}_{16} \mathrm{H}_{13} \mathrm{NO}_{3}$, 267.09009; found, 267.09030.

\section{2,2,6,6-Tetramethyl-1-(1-(2-(4-nitrophenyl)benzofuran-5-} yl)ethoxy)piperidine (2b). Under air, TEMPO (46.8 mg, $0.3 \mathbf{m m o l})$, 5-ethyl-2-(4-nitrophenyl)benzofuran (5b, $267 \mathrm{mg}$, $1 \mathrm{mmol}), \mathrm{Cu}(\mathrm{OAc})_{2}(3.6 \mathrm{mg}, 0.02 \mathrm{mmol})$, bpy $(3.1 \mathrm{mg}$, $0.02 \mathrm{mmol}$ ), TBHP (aqueous $70 \%, 0.086 \mathrm{~mL}, 0.6 \mathrm{mmol}$ ) were added into a Schlenk tube in the dark. The reaction was stirred at $60{ }^{\circ} \mathrm{C}$ for $16.5 \mathrm{~h}$. Upon completion, the mixture was purified by silica gel column chromatography (hexane/ether $15: 1, \mathrm{v} / \mathrm{v}$ ) to give $2 \mathrm{~b}(66 \mathrm{mg}, 52 \%)$. mp $144{ }^{\circ} \mathrm{C}$; IR $\left(\mathrm{KBr}, \mathrm{cm}^{-1}\right)$ : 2922, 1602 , 1520, 1342, 1108, 852, 746; ${ }^{1} \mathrm{H}$ NMR (400 MHz, $\left.\mathrm{CDCl}_{3}\right) \delta$ (ppm) $8.31(\mathrm{~d}, J=9.0 \mathrm{~Hz}, 2 \mathrm{H}), 7.99(\mathrm{~d}, J=9.0 \mathrm{~Hz}, 2 \mathrm{H}), 7.57$ $(\mathrm{d}, J=1.6 \mathrm{~Hz}, 1 \mathrm{H}), 7.50(\mathrm{~d}, J=8.6 \mathrm{~Hz}, 1 \mathrm{H}), 7.36(\mathrm{dd}, J=8.6$, $1.7 \mathrm{~Hz}, 1 \mathrm{H}), 7.23(\mathrm{~s}, 1 \mathrm{H}), 4.88(\mathrm{q}, J=6.6 \mathrm{~Hz}, 1 \mathrm{H}), 1.53(\mathrm{~d}, J=$ $6.7 \mathrm{~Hz}, 3 \mathrm{H}), 1.51$ (s, 3H), $1.33(\mathrm{~s}, 6 \mathrm{H}), 1.19(\mathrm{~s}, 3 \mathrm{H}), 1.02$ (s, $3 \mathrm{H}), 0.60(\mathrm{~s}, 3 \mathrm{H}) ;{ }^{13} \mathrm{C} \mathrm{NMR}\left(100 \mathrm{MHz}, \mathrm{CDCl}_{3}\right) \delta(\mathrm{ppm}) 154.75$ (C), 153.43 (C), 147.24 (C), 141.55 (C), 136.47 (C), 128.34 (C), $125.15(\mathrm{CH}), 125.04(\mathrm{CH}), 124.32(\mathrm{CH}), 119.50(\mathrm{CH}), 110.98$ $(\mathrm{CH}), 105.39(\mathrm{CH}), 83.13(\mathrm{CH}), 59.76(\mathrm{C}), 40.42\left(\mathrm{CH}_{2}\right), 34.37$ $\left(\mathrm{CH}_{3}\right), 23.78\left(\mathrm{CH}_{2}\right), 20.38\left(\mathrm{CH}_{3}\right), 17.24\left(\mathrm{CH}_{3}\right)$; HRMS-ESI $(m / z):[\mathrm{M}+\mathrm{H}]^{+}$calcd. for $\mathrm{C}_{25} \mathrm{H}_{30} \mathrm{~N}_{2} \mathrm{O}_{4} ; 423.22783$; found 423.22757 .

1-(2-(4-Nitrophenyl)benzofuran-6-yl)ethan-1-ol (6a). mp $133{ }^{\circ} \mathrm{C} ;{ }^{1} \mathrm{H}$ NMR $\left(400 \mathrm{MHz}, \mathrm{CDCl}_{3}\right) \delta(\mathrm{ppm}) 8.31(\mathrm{~d}, J=$ $9.0 \mathrm{~Hz}, 2 \mathrm{H}), 7.99$ (d, $J=9.0 \mathrm{~Hz}, 2 \mathrm{H}), 7.61(\mathrm{~d}, J=7.7 \mathrm{~Hz}, 1 \mathrm{H})$, $7.61(\mathrm{~s}, 1 \mathrm{H}), 7.30(\mathrm{dd}, J=8.1,1.3 \mathrm{~Hz}, 1 \mathrm{H}), 7.22(\mathrm{~s}, 1 \mathrm{H}), 5.06$ $(\mathrm{m}, 1 \mathrm{H}), 1.90(\mathrm{~d}, J=3.6 \mathrm{~Hz}, 1 \mathrm{H}), 1.57(\mathrm{~d}, J=6.5 \mathrm{~Hz}, 3 \mathrm{H})$; ${ }^{13} \mathrm{C}$ NMR $\left(100 \mathrm{MHz}, \mathrm{CDCl}_{3}\right) \delta(\mathrm{ppm}) 155.72(\mathrm{C}), 153.61(\mathrm{C})$, $147.24(\mathrm{C}), 144.47(\mathrm{C}), 136.26(\mathrm{C}), 127.96(\mathrm{C}), 125.16(\mathrm{CH})$, $124.34(\mathrm{CH}), 121.56(\mathrm{CH}), 121.34(\mathrm{CH}), 108.33(\mathrm{CH}), 104.97$ $(\mathrm{CH}), 70.50(\mathrm{CH}), 25.58\left(\mathrm{CH}_{3}\right)$.

1-(2-(4-Nitrophenyl)benzofuran-5-yl)ethan-1-ol (6b). mp $149{ }^{\circ} \mathrm{C} ;{ }^{1} \mathrm{H}$ NMR $\left(400 \mathrm{MHz}, \mathrm{CDCl}_{3}\right) \delta(\mathrm{ppm}) 8.30(\mathrm{~d}, J=$ 
$9.0 \mathrm{~Hz}, 2 \mathrm{H}), 7.99$ (d, $J=9.0 \mathrm{~Hz}, 2 \mathrm{H}), 7.66(\mathrm{~s}, 1 \mathrm{H}), 7.53$ (d, $J=$ $8.5 \mathrm{~Hz}, 1 \mathrm{H}), 7.39$ (dd, $J=8.5,1.7 \mathrm{~Hz}, 1 \mathrm{H}), 7.22(\mathrm{~s}, 1 \mathrm{H}), 5.04$ (q, $J=6.4 \mathrm{~Hz}, 1 \mathrm{H}), 1.88(\mathrm{~s}, 1 \mathrm{H}), 1.57$ (d, $J=6.4 \mathrm{~Hz}, 3 \mathrm{H})$; ${ }^{13} \mathrm{C} \mathrm{NMR}\left(100 \mathrm{MHz}, \mathrm{CDCl}_{3}\right) \delta(\mathrm{ppm}) 154.93(\mathrm{C}), 153.81(\mathrm{C})$, 147.29 (C), 141.48 (C), 136.22 (C), $128.74(\mathrm{C}), 125.24(\mathrm{CH})$, $124.32(\mathrm{CH}), 123.67(\mathrm{CH}), 118.28(\mathrm{CH}), 111.45(\mathrm{CH}), 105.14$ $(\mathrm{CH}), 70.47(\mathrm{CH}), 25.64\left(\mathrm{CH}_{3}\right)$; HRMS-ESI $(\mathrm{m} / \mathrm{z})$ : [ $\left.\mathrm{M}^{-}\right]$calcd. for $\mathrm{C}_{16} \mathrm{H}_{13} \mathrm{NO}_{4}, 283.08501$; found, 283.08548 .

1-(2-(4-Nitrophenyl)benzofuran-6-yl)ethan-1-one (7a). $\mathrm{mp}$ $214{ }^{\circ} \mathrm{C} ;{ }^{1} \mathrm{H}$ NMR $\left(400 \mathrm{MHz}, \mathrm{CDCl}_{3}\right) \delta(\mathrm{ppm}) 8.35(\mathrm{~d}, J=$ $8.9 \mathrm{~Hz}, 2 \mathrm{H}), 8.18(\mathrm{~s}, 1 \mathrm{H}), 8.05(\mathrm{~d}, J=8.9 \mathrm{~Hz}, 1 \mathrm{H}), 7.93$ (dd, $J=$ 8.2, 1.3 Hz, 1H), $7.71(\mathrm{~d}, J=8.2 \mathrm{~Hz}, 1 \mathrm{H}), 7.29$ (s, 1H), 2.70 (s, $3 \mathrm{H}) ;{ }^{13} \mathrm{C} \mathrm{NMR}\left(100 \mathrm{MHz}, \mathrm{CDCl}_{3}\right) \delta(\mathrm{ppm}) 197.22(\mathrm{C}), 156.45$ (C), $155.12(\mathrm{C}), 147.82(\mathrm{C}), 135.52(\mathrm{C}), 134.84(\mathrm{C}), 132.93$ (C), $125.76(\mathrm{CH}), 124.41(\mathrm{CH}), 123.88(\mathrm{CH}), 121.41(\mathrm{CH}), 111.79$ $(\mathrm{CH}), 104.85(\mathrm{CH}), 26.86\left(\mathrm{CH}_{3}\right)$.

1-(2-(4-Nitrophenyl)benzofuran-5-yl)ethan-1-one (7b). $\mathrm{mp}$ $229{ }^{\circ} \mathrm{C} ;{ }^{1} \mathrm{H}$ NMR $\left(400 \mathrm{MHz}, \mathrm{CDCl}_{3}\right) \delta(\mathrm{ppm}) 8.34(\mathrm{~d}, J=$ $9.0 \mathrm{~Hz}, 2 \mathrm{H}), 8.30(\mathrm{~s}, 1 \mathrm{H}), 8.04(\mathrm{~d}, J=8.6 \mathrm{~Hz}, 1 \mathrm{H}), 8.03(\mathrm{~d}, J=$ $9.0 \mathrm{~Hz}, 2 \mathrm{H}), 7.62(\mathrm{~d}, J=8.7,1 \mathrm{H}), 7.32(\mathrm{~s}, 1 \mathrm{H}), 2.69(\mathrm{~s}, 3 \mathrm{H})$; ${ }^{13} \mathrm{C}$ NMR (100 MHz, $\left.\mathrm{CDCl}_{3}\right) \delta(\mathrm{ppm}) 197.35(\mathrm{C}), 157.84(\mathrm{C})$, 154.86 (C), 147.63 (C), 135.59 (C), 133.41 (C), 128.79 (C), $126.38(\mathrm{CH}), 125.51(\mathrm{CH}), 124.40(\mathrm{CH}), 122.86(\mathrm{CH}), 111.57$ $(\mathrm{CH}), 105.38(\mathrm{CH}), 26.82\left(\mathrm{CH}_{3}\right)$; HRMS-ESI $(\mathrm{m} / \mathrm{z}):\left[\mathrm{M}^{-}\right]$ calcd. for $\mathrm{C}_{16} \mathrm{H}_{11} \mathrm{NO}_{4}, 281.06936$; found, 281.06970 .

\section{Photoirradiation of LLC cells with compound}

\section{2a}

One hundred thousand Lewis lung carcinoma (LLC) cells were seeded into a 24-well plate (medium: DMEM) and incubated overnight at $37{ }^{\circ} \mathrm{C}$ in an atmosphere of $95 \%$ air and $5 \% \mathrm{CO}_{2}$. The medium was replaced with fresh phenol-red free DMEM containing $100 \mu \mathrm{g} / \mathrm{mL}$ of compound 2a. Four hours after various irradiation time of $360 \mathrm{~nm}$ light $(0,10,30,60,90,120$, and $150 \mathrm{~s}$ ) using a fluorescence microscope (BIOREVO BZ-9000, Keyence, Osaka, Japan), cell viability was determined by trypan blue exclusion. Bars represent the mean \pm standard deviation $(n=4)$.

\section{Detection of intracellular ROS in irradiated LLC cells with 2 a-containing medium}

Fifty thousand Lewis lung carcinoma (LLC) cells were seeded into 24-well plate (medium: DMEM) and incubated overnight at $37{ }^{\circ} \mathrm{C}$ in an atmosphere of $95 \%$ air and $5 \% \mathrm{CO}_{2}$. The medium was replaced with fresh phenol-red free DMEM containing 0 or $100 \mu \mathrm{g} / \mathrm{mL}$ of compound $\mathbf{2 a}$. Thirty minutes after $1 \mathrm{~min}$ or no exposure of $360 \mathrm{~nm}$ light using a fluorescence microscope (BIOREVO BZ-9000, Keyence, Osaka, Japan), intracellular ROS were detected using the ROS-ID Oxidative Stress Detec- tion Kit (Enzo Life Sciences, Farmingdale, NY, USA) in conjunction with fluorescence microscopy. Intracellular ROS was detected in the form of green fluorescence signals. Bars, $100 \mu \mathrm{m}$.

\section{Supporting Information}

\section{Supporting Information File 1}

${ }^{1} \mathrm{H}$ and ${ }^{13} \mathrm{C}$ NMR charts for new compounds and Figures S1-S8.

[https://www.beilstein-journals.org/bjoc/content/ supplementary/1860-5397-15-84-S1.pdf]

\section{Acknowledgements}

The NMR and MS measurements were performed at N-BARD, Hiroshima University. This work was supported by a Grant-inAid for Scientific Research JP17H0302200 from the Ministry of Education, Culture, Sports, Science and Technology, Japan. This work was partly supported by a research grant from Takahashi Industrial and Economic Research Foundation.

\section{ORCID ${ }^{\circledR}$ iDs}

Ayato Yamada - https://orcid.org/0000-0002-0631-0806 Manabu Abe - https://orcid.org/0000-0002-2013-4394 Yoshinobu Nishimura - https://orcid.org/0000-0002-9982-141X Shoji Ishizaka - https://orcid.org/0000-0001-9866-5809 Taku Nakashima - https://orcid.org/0000-0002-0035-674X Kiyofumi Shimoji - https://orcid.org/0000-0001-5382-4730

\section{References}

1. Keana, J. F. W. Chem. Rev. 1978, 78, 37-64. doi:10.1021/cr60311a004

2. Janzen, E. G. Acc. Chem. Res. 1971, 4, 31-40. doi:10.1021/ar50037a005

3. Eckert, H. Chem. - Eur. J. 2017, 23, 5893-5914. doi:10.1002/chem.201604685

4. Krumkacheva, O.; Bagryanskaya, E. J. Magn. Reson. 2017, 280, 117-126. doi:10.1016/j.jmr.2017.02.015

5. Kim, N.-K.; Murali, A.; DeRose, V. J. Chem. Biol. 2004, 11, 939-948. doi:10.1016/j.chembiol.2004.04.013

6. Sicoli, G.; Wachowius, F.; Bennati, M.; Höbartner, C. Angew. Chem., Int. Ed. 2010, 49, 6443-6447. doi:10.1002/anie.201000713

7. Weinrich, T.; Jaumann, E. A.; Scheffer, U. M.; Prisner, T. F.; Göbel, M. W. Beilstein J. Org. Chem. 2018, 14, 1563-1569. doi:10.3762/bjoc.14.133

8. Kakavandi, R.; Ravat, P.; Savu, S.-A.; Borozdina, Y. B.; Baumgarten, M.; Casu, M. B. ACS Appl. Mater. Interfaces 2015, 7, 1685-1692. doi:10.1021/am508854u

9. Krishna, M. C.; English, S.; Yamada, K.; Yoo, J.; Murugesan, R.; Devasahayam, N.; Cook, J. A.; Golman, K.; Ardenkjaer-Larsen, J. H.; Subramanian, S.; Mitchell, J. B. Proc. Natl. Acad. Sci. U. S. A. 2002, 99, 2216-2221. doi:10.1073/pnas.042671399 
10. Hall, D. A.; Maus, D. C.; Gerfen, G. J.; Inati, S. J.; Becerra, L. R.; Dahlquist, F. W.; Griffin, R. G. Science 1997, 276, 930-932. doi:10.1126/science.276.5314.930

11. Matsuki, Y.; Maly, T.; Ouari, O.; Karoui, H.; Le Moigne, F.; Rizzato, E.; Lyubenova, S.; Herzfeld, J.; Prisner, T.; Tordo, P.; Griffin, R. G. Angew. Chem., Int. Ed. 2009, 48, 4996-5000. doi:10.1002/anie.200805940

12. Bagryanskaya, E. G.; Marque, S. R. A. Chem. Rev. 2014, 114, 5011-5056. doi:10.1021/cr4000946

13. Abe, M. Chem. Rev. 2013, 113, 7011-7088. doi:10.1021/cr400056a

14. Nishide, H.; Oyaizu, K. Science 2008, 319, 737-738. doi:10.1126/science.1151831

15. Oltean, V.-A.; Renault, S.; Valvo, M.; Brandell, D. Materials 2016, 9 , No. 142. doi:10.3390/ma9030142

16. Kermagoret, A.; Gigmes, D. Tetrahedron 2016, 72, 7672-7685. doi:10.1016/j.tet.2016.07.002

17. Guégain, E.; Guillaneuf, Y.; Nicolas, J. Macromol. Rapid Commun. 2015, 36, 1227-1247. doi:10.1002/marc.201500042

18. Nicolas, J.; Guillaneuf, Y.; Lefay, C.; Bertin, D.; Gigmes, D.; Charleux, B. Prog. Polym. Sci. 2013, 38, 63-235. doi:10.1016/j.progpolymsci.2012.06.002

19. Bertin, D.; Gigmes, D.; Marque, S. R. A.; Tordo, P. Chem. Soc. Rev. 2011, 40, 2189-2198. doi:10.1039/c0cs00110d

20. Hawker, C. J.; Bosman, A. W.; Harth, E. Chem. Rev. 2001, 101, 3661-3688. doi:10.1021/cr990119u

21. Huple, D. B.; Ghorpade, S.; Liu, R.-S. Adv. Synth. Catal. 2016, 358, 1348-1367. doi:10.1002/adsc.201600018

22. Ciriminna, R.; Palmisano, G.; Pagliaro, M. ChemCatChem 2015, 7, 552-558. doi:10.1002/cctc. 201402896

23. Cao, Q.; Dornan, L. M.; Rogan, L.; Hughes, N. L.; Muldoon, M. J. Chem. Commun. 2014, 50, 4524-4543. doi:10.1039/c3cc47081d

24. Wertz, S.; Studer, A. Green Chem. 2013, 15, 3116-3134. doi:10.1039/c3gc41459k

25. Tebben, L.; Studer, A. Angew. Chem., Int. Ed. 2011, 50, 5034-5068. doi:10.1002/anie.201002547

26. Goeldner, M.; Givens, R., Eds. Dynamic Studies in Biology; Wiley-VCH: Weinheim, 2005.

27. Soule, B. P.; Hyodo, F.; Matsumoto, K.; Simone, N. L.; Cook, J. A.; Krishna, M. C.; Mitchell, J. B. Free Radical Biol. Med. 2007, 42, 1632-1650. doi:10.1016/j.freeradbiomed.2007.02.030

28. Hoye, A. T.; Davoren, J. E.; Wipf, P.; Fink, M. P.; Kagan, V. E. Acc. Chem. Res. 2008, 41, 87-97. doi:10.1021/ar700135m

29. Oliveira, C.; Benfeito, S.; Fernandes, C.; Cagide, F.; Silva, T.; Borges, F. Med. Res. Rev. 2018, 38, 1159-1187. doi:10.1002/med.21461

30. Matsuoka, Y.; Yamato, M.; Yamada, K.-i. J. Clin. Biochem. Nutr. 2016, 58, 16-22. doi:10.3164/jcbn.15-105

31. Wilcox, C. S. Pharmacol. Ther. 2010, 126, 119-145. doi:10.1016/j.pharmthera.2010.01.003

32. Prescott, C.; Bottle, S. E. Cell Biochem. Biophys. 2017, 75, 227-240. doi:10.1007/s12013-016-0759-0

33. Scaiano, J. C.; Connolly, T. J.; Mohtat, N.; Pliva, C. N. Can. J. Chem. 1997, 75, 92-97. doi:10.1139/v97-014

34. Guillaneuf, Y.; Bertin, D.; Gigmes, D.; Versace, D.-L.; Lalevée, J.; Fouassier, J.-P. Macromolecules 2010, 43, 2204-2212. doi:10.1021/ma902774s

35. Versace, D.-L.; Lalevée, J.; Fouassier, J.-P.; Gigmes, D.; Guillaneuf, Y.; Bertin, D. J. Polym. Sci., Part A: Polym. Chem. 2010, 48, 2910-2915. doi:10.1002/pola.24071
36. Yoshida, E. Colloid Polym. Sci. 2010, 288, 1639-1643. doi:10.1007/s00396-010-2287-6

37. Kelkar, S. S.; Reineke, T. M. Bioconjugate Chem. 2011, 22, 1879-1903. doi:10.1021/bc200151q

38. Melancon, M. P.; Zhou, M.; Li, C. Acc. Chem. Res. 2011, 44, 947-956. doi:10.1021/ar200022e

39. Chen, G.; Qiu, H.; Prasad, P. N.; Chen, X. Chem. Rev. 2014, 114, 5161-5214. doi:10.1021/cr400425h

40. Lim, E.-K.; Kim, T.; Paik, S.; Haam, S.; Huh, Y.-M.; Lee, K. Chem. Rev. 2015, 115, 327-394. doi:10.1021/cr300213b

41. Audran, G.; Brémond, P.; Franconi, J.-M.; Marque, S. R. A.; Massot, P.; Mellet, P.; Parzy, E.; Thiaudière, E. Org. Biomol. Chem. 2014, 12, 719-723. doi:10.1039/c3ob42076k

42. Audran, G.; Brémond, P.; Marque, S. R. A. Chem. Commun. 2014, 50, 7921-7928. doi:10.1039/c4cc01364f

43. Luo, Y.-R. Handbook of Bond Dissociation Energies in Organic Compounds; CRC Press: Boca Raton, FL, U.S.A., 2002; p 215.

44. Göppert-Mayer, M. Ann. Phys. (Berlin, Ger.) 1931, 401, 273-294. doi:10.1002/andp.19314010303

45. Boyd, M. Non-Linear Optics, 2nd ed.; Elsevier: London, 2003.

46. Kawata, S.; Sun, H.-B.; Tanaka, T.; Takada, K. Nature 2001, 412, 697-698. doi:10.1038/35089130

47. Momotake, A.; Lindegger, N.; Niggli, E.; Barsotti, R. J.; Ellis-Davies, G. C. R. Nat. Methods 2006, 3, 35-40. doi:10.1038/nmeth821

48. Matsuzaki, M.; Ellis-Davies, G. C. R.; Nemoto, T.; Miyashita, Y.; lino, M.; Kasai, H. Nat. Neurosci. 2001, 4, 1086-1092. doi:10.1038/nn736

49. Mayer, G.; Heckel, A. Angew. Chem., Int. Ed. 2006, 45, 4900-4921. doi:10.1002/anie.200600387

50. Ellis-Davies, G. C. R. ACS Chem. Neurosci. 2011, 2, 185-197. doi:10.1021/cn100111a

51. Bort, G.; Gallavardin, T.; Ogden, D.; Dalko, P. I. Angew. Chem., Int. Ed. 2013, 52, 4526-4537. doi:10.1002/anie.201204203

52. Terenziani, F.; Katan, C.; Badaeva, E.; Tretiak, S.; Blanchard-Desce, M. Adv. Mater. (Weinheim, Ger.) 2008, 20 , 4641-4678. doi:10.1002/adma.200800402

53. Papageorgiou, G.; Ogden, D. C.; Barth, A.; Corrie, J. E. T. J. Am. Chem. Soc. 1999, 121, 6503-6504. doi:10.1021/ja990931e

54. Matsuzaki, M.; Hayama, T.; Kasai, H.; Ellis-Davies, G. C. R. Nat. Chem. Biol. 2010, 6, 255-257. doi:10.1038/nchembio.321

55. Baron, M.; Morris, J. C.; Telitel, S.; Clément, J.-L.; Lalevée, J.; Morlet-Savary, F.; Spangenberg, A.; Malval, J.-P.; Soppera, O.; Gigmes, D.; Guillaneuf, Y. J. Am. Chem. Soc. 2018, 140, 3339-3344. doi:10.1021/jacs.7b12807

56. Klán, P.; Šolomek, T.; Bochet, C. G.; Blanc, A.; Givens, R.; Rubina, M.; Popik, V.; Kostikov, A.; Wirz, J. Chem. Rev. 2013, 113, 119-191. doi:10.1021/cr300177k

57. Jakkampudi, S.; Abe, M. In Elsevier Reference Module in Chemistry, Molecular Sciences and Chemical Engineering, 2018, Chapter 13667.

58. Chitose, Y.; Abe, M. Design and synthesis of two-photon responsive chromophores for application to uncaging reactions. Photochemistry; The Royal Society of Chemistry, 2018; Vol. 46, pp 219-241. doi:10.1039/9781788013598-00219

59. Abe, M.; Chitose, Y.; Jakkampudi, S.; Thuy, P. T. T.; Lin, Q.; Van, B. T.; Yamada, A.; Oyama, R.; Sasaki, M.; Katan, C. Synthesis 2017, 49, 3337-3346. doi:10.1055/s-0036-1590813

60. Boinapally, S.; Huang, B.; Abe, M.; Katan, C.; Noguchi, J.; Watanabe, S.; Kasai, H.; Xue, B.; Kobayashi, T. J. Org. Chem. 2014, 79, 7822-7830. doi:10.1021/jo501425p 
61. Komori, N.; Jakkampudi, S.; Motoishi, R.; Abe, M.; Kamada, K.; Furukawa, K.; Katan, C.; Sawada, W.; Takahashi, N.; Kasai, H.; Xue, B.; Kobayashi, T. Chem. Commun. 2016, 52, 331-334. doi:10.1039/c5cc07664a

62. Jakkampudi, S.; Abe, M.; Komori, N.; Takagi, R.; Furukawa, K.; Katan, C.; Sawada, W.; Takahashi, N.; Kasai, H. ACS Omega 2016, 1 , 193-201. doi:10.1021/acsomega.6b00119

63. Chitose, Y.; Abe, M.; Furukawa, K.; Katan, C. Chem. Lett. 2016, 45, 1186-1188. doi:10.1246/cl.160586

64. Chitose, Y.; Abe, M.; Furukawa, K.; Lin, J.-Y.; Lin, T.-C.; Katan, C. Org. Lett. 2017, 19, 2622-2625. doi:10.1021/acs.orglett.7b00957

65. Fukuhara, K.; Nakashima, T.; Abe, M.; Masuda, T.; Hamada, H.; Iwamoto, H.; Fujitaka, K.; Kohno, N.; Hattori, N. Free Radical Biol. Med. 2017, 106, 1-9. doi:10.1016/j.freeradbiomed.2017.02.014

66. Noh, J.; Kwon, B.; Han, E.; Park, M.; Yang, W.; Cho, W.; Yoo, W.; Khang, G.; Lee, D. Nat. Commun. 2015, 6, No. 6907. doi:10.1038/ncomms7907

67. Lewandowski, M.; Gwozdzinski, K. Int. J. Mol. Sci. 2017, 18, No. 2490. doi:10.3390/ijms18112490

68. Bosiak, M. J. ACS Catal. 2016, 6, 2429-2434. doi:10.1021/acscatal.6b00190

69. Li, L.; Yu, Z.; Shen, Z. Adv. Synth. Catal. 2015, 357, 3495-3500. doi:10.1002/adsc.201500544

70. Zimmerman, H. E. J. Am. Chem. Soc. 1995, 117, 8988-8991. doi:10.1021/ja00140a014

\section{License and Terms}

This is an Open Access article under the terms of the Creative Commons Attribution License (http://creativecommons.org/licenses/by/4.0). Please note that the reuse, redistribution and reproduction in particular requires that the authors and source are credited.

The license is subject to the Beilstein Journal of Organic Chemistry terms and conditions:

(https://www.beilstein-journals.org/bjoc)

The definitive version of this article is the electronic one which can be found at: $\underline{\text { doi: } 10.3762 / \text { bjoc. } 15.84}$ 